\title{
BUDI DAYA KELAPA DAN PEMASARAN KOPRA DI BUOL 1970-2019
}

\section{THE COCONUT CULTIVATION AND COPRA MARKETING IN BUOL 1970-2019}

\author{
Jhon Rivel Purba dan Wilman D. Lumangino \\ Pusat Penelitian Arkeologi Nasional, Universitas Tadulako, Palu, Indonesia \\ kap_jho@yahoo.com,wdlumangino@gmail.com
}

Diterima tanggal 11 Februari 2021

Disetujui tanggal 25 November 2021

\begin{abstract}
As the price of copra increased in the global market, coconut cultivation in Buol received great attention in the early $20^{\text {th }}$ century. During the New Order, the government paid attention again to people's plantations, especially coconuts. Coconut cultivation was promoted in several areas, including Buol. This paper scrutinizes the cultivation process and development of copra production in Buol. The commodities were closely related because the cultivation process greatly affected the production of copra. This study used the historical method to suggest that the people of Buol were cultivating coconut because of its great benefits, including how easy it was to be processed. In addition, other findings of this study indicate that the price of copra at the plantation level was determined by interconnected factors such as the quality of copra, the marketing network, and the absence of koperasi (economic enterprise) as a market counterweight. The study also found that although they were seen as economic symbols for the Buolese, these two commodities did not contribute significantly to the welfare of Buolese, particularly the small farmers who do not have vast cultivating lands.
\end{abstract}

Keywords: coconut cultivation, copra production, history, socio-economics, and Buol.

\begin{abstract}
ABSTRAK
Budi daya kelapa di Buol mendapat perhatian besar pada awal abad ke-20 seiring dengan meningkatnya harga kopra di pasar dunia. Pada masa Orde Baru, pemerintah kembali memperhatikan perkebunan rakyat khususnya kelapa. Budi daya kelapa pun digalakkan di beberapa wilayah termasuk di Buol. Tulisan ini menggambarkan proses budi daya dan perkembangan produksi kopra di Buol. Dua hal ini sangat berkait erat, karena proses budi daya sangat memengaruhi hasil produksi kopra. Kajian yang menggunakan metode sejarah ini menunjukkan bahwa penduduk Buol membudidayakan kelapa karena manfaatnya yang besar dan tanaman ini relatif mudah untuk dibudidayakan. Selain itu, temuan lain memperlihatkan bahwa tinggi rendahnya harga kopra di tingkat petani disebabkan oleh kualitas kopra, lapisan jaringan pemasaran, dan tidak adanya koperasi sebagai penyeimbang
\end{abstract}


Handep Jurnal Sejarah dan Budaya

pasar. Hasil penelitian ini juga menemukan fakta bahwa meskipun dipandang sebagai simbol ekonomi bagi masyarakat Buol, kedua komoditas ini tidak memberikan kontribusi terhadap kehidupan ekonomi masyarakat kecil, khususnya petani yang tidak memiliki lahan budi daya luas.

Kata kunci: budi daya kelapa, produksi kopra, sejarah, sosial-ekonomi, dan Buol.

\section{A. PENDAHULUAN}

Kelapa (Cocos nucifera) memiliki sejarah panjang di Indonesia. Persebarannya cukup luas, baik melalui budi daya maupun tumbuh secara alamiah. Tanaman ini pertama kali diperkenalkan oleh pemerintah kolonial Hindia Belanda. Keberadaan onderneming (perkebunan) di Hindia Belanda telah memengaruhi pola tanam kelapa yang lebih teratur. Selain untuk memenuhi kebutuhan sehari-hari, kelapa diolah menjadi kopra. Pada 1870-1915, kopra telah diproduksi dan dipasarkan hingga ke Jawa dan Singapura. Salah satu pusat perdagangan pada masa itu adalah Kampung Bugis di Buol. Kampung ini merupakan kawasan permukiman para pendatang dari Sulawesi Selatan (Henley, 2005:217). Kelapa semakin dikenal luas oleh masyarakat Buol sekitar abad XIX (Samad, 2002:74).

Tulisan ini membahas bagaimana kelapa dibudidayakan, termasuk perkembangan produksi dan pemasaran kopra di Buol pada periode 1970-2019. Rentang waktu ini diambil dengan melihat gejala sejarah yang terjadi dalam rentang waktu tersebut. Pada 1970 petani kelapa di Buol melakukan peremajaan pohon-pohon kelapa mereka yang tidak produktif lagi. Hal ini dilakukan karena pada setahun sebelumnya, lima buah koperasi kopra beroperasi di Buol. Sementara itu, pada 2019 sebuah usaha baru yang memproduksi kopra putih diujicobakan di Bongo, Kecamatan Bokat, Kabupaten Buol. Kopra putih sangat tinggi harga jualnya, sehingga dapat meningkatkan pendapatan petani.

Melalui penelusuran berbagai literatur, belum ditemukan tulisan yang membahas tentang budi daya kelapa dan perkembangan produksi kopra di Buol. Tulisan Awang (1994) memberikan gambaran perkebunan kelapa di Indonesia yang meliputi sejarah, budi daya, ekonomi kelapa, industri pengolahan kelapa, pemasaran kelapa, sosial ekonomi petani kelapa, dan kecenderungan bisnis kelapa di Indonesia. Selain itu, tulisan Soetedjo (1969) juga memberikan gambaran umum tentang cara bercocok tanam kelapa hingga pengolahan hasilnya. Karya Asba (2003) memberi pemahaman umum tentang perdagangan kopra. Komoditas penting ini menjanjikan pendapatan ekonomi yang tinggi, sehingga mengundang banyak pihak untuk "berebut" pengelolaan sumber daya ini. Oleh karena itu, perdagangan kopra harus dikontrol agar tidak merugikan negara (pusat) dan petani. Dari beberapa studi tersebut, tidak ada yang menyinggung budi daya kelapa dan produksi kopra di Buol.

Buol memiliki kelapa unggul yang berpotensi untuk dikembangkan seperti yang ditulis Tenda (2014). Hanya saja, dalam tulisan ini tidak dijelaskan budi daya kelapa seperti apa yang telah 
dilakukan petani di Buol. Oleh karena itu, tulisan ini hendak menyelami lebih jauh soal budi daya kelapa dan produksi kopra di Buol. Berdasarkan beberapa studi yang telah disampaikan di atas, kedua hal tersebut belum dibicarakan sama sekali.

Fenomena sejarah ekonomi di Buol pada periode 1970-2019 dapat dijelaskan dengan melihat faktor produksi, budi daya, dan pemasarannya. Menurut Daniel (2002:50), faktor produksi terdiri atas empat komponen, yaitu tanah, modal, tenaga kerja, dan manajemen (pengolahan). Setiap proses (produksi) mempunyai awal dan akhir. Begitu pula dengan budi daya kelapa di Buol. Paling tidak ada lima tahapannya, yakni pembibitan, penyiapan lahan, penanaman, pemeliharaan, dan panen (Mardiatmoko et.al, 2011:54-177). Terkait dengan bibit kelapa, setiap petani memiliki metode sendiri dalam menyiapkan bibit. Demikian juga dengan lahan untuk budi daya yang tidak pernah sama luasnya. Bagi masyarakat Buol, luas lahan ditentukan melalui jumlah pohon kelapa yang dimiliki. Pemilik lahan budi daya yang luas tidak banyak jumlahnya di daerah itu. Pola pemeliharaan juga masih seperti yang diwariskan oleh generasi sebelumnya. Hasil panen masih dikelola dengan model lama, yakni hanya menghasilkan kopra untuk dijual kepada para pedagang di Buol. Harga kopra mengalami perubahan yang signifikan. Perkembangan dari unit terkecil sampai yang terbesar adalah proses progresif melalui fase-fase tertentu yang terkadang berbeda satu sama lainnya. Hal ini mengakibatkan perluasan ruang lingkup dan skala ekonomi, kemasyarakatan (society), politik dan budaya. Kekuatan-kekuatan dari dalam dan dari luar pun ikut memberi pengaruh dalam melihat perkembangan itu (Kartodirdjo, 2017:xxii).

Budi daya kelapa dan produksi kopra di Buol cukup menarik karena perkembangan produksi dua komoditas itu dapat menjelaskan sejarah ekonomi masyarakatnya mulai dari persoalan budi daya hingga dinamika produksi. Melalui dua hal itu, terlihat dengan jelas bila petani kelapa selalu dirugikan oleh banyak pihak, tidak hanya pedagang pengumpul maupun pengepul, tapi juga para pengusaha (kapitalis) perkebunan kelapa dan oleh pemerintah sendiri.

\section{B. METODE}

Kelapa dan tentunya kopra merupakan bagian terpenting dari kehidupan ekonomi itu sendiri. Sejak zaman kolonial, bahkan mungkin jauh sebelumnya, masyarakat Buol telah mengenal kelapa dan produk turunannya tersebut. Untuk itu, penulis menggunakan metode sejarah guna mengungkapkan berbagai peristiwa yang berkaitan dengan kelapa dan kopra.

Penelitian ini dipusatkan, khususnya ketika melakukan penelitian lapangan, di Kecamatan Bokat, Kabupaten Buol. Walaupun begitu, beberapa tempat lainnya, seperti Bunobagu, Bukal, Momunu, Leok, dan Gadung, tetap dikunjungi guna mencari data bandingan. Pemilihan Bokat disebabkan oleh fakta bahwa kecamatan ini tidak begitu luas, namun produki kelapa di sana telah menjadi simbol ekonomi bagi masyarakatnya. 
Handep Jurnal Sejarah dan Budaya Vol. 5, No. 1, Desember 2021, hlm. 27-48

Sebagian besar kebutuhan ekonomi masyarakat ditopang oleh budi daya kelapa walau harga jual komoditas hasil produksinya seringkali tidak sesuai harapan. Apalagi setelah "jatuhnya" koperasi kopra di Buol pada 2012. Selama periode 2012-2020 peran koperasi kopra diambil alih pedagang Tionghoa, tetapi petani tetap mengeluh soal harga kopra yang tidak pernah menguntungkan mereka.

Sumber sejarah yang digunakan antara lain literatur berupa karya-karya ilmiah, buku populer, dan media massa sezaman. Tidak kalah penting juga adalah sumber dari Badan Pusat Statistik (BPS) Kabupaten Buol sebagai data umum yang menjadi titik tolak tulisan ini. Selain sumber tertulis, juga digunakan sumber sejarah lisan dari hasil wawancara. Ini dilakukan karena sifat sumber tersebut yang dapat melengkapi dan mengisi kekosongan tersebut. Melalui wawancara tidak terstruktur, penulis berhasil mendapat informasi yang berkaitan dengan topik tulisan ini. Para informan diseleksi berdasarkan pekerjaan dan status sosial mereka. Ada elit desa, petani kaya, petani kecil, tukang panjat, pemilik gerobak, pedagang pengumpul, pengepul, petani sawit, dan Aparatur Sipil Negara (ASN). Kemudian dilakukan cek silang antara sumber lisan dan sumber tertulis, tujuannya agar menjaga validitas dan keabsahan sumber. Hasilnya adalah terbentuknya fakta yang saling melengkapi guna memudahkan penulis melakukan penafsiran. Jalinan fakta membuat narasi sejarah yang dibangun menjadi kuat.

\section{HASIL DAN BAHASAN \\ 1. Fakta Geografi Buol}

Buol merupakan sebuah kampung yang dipimpin oleh jogugu bernama Balamagile. Jogugu adalah sebuah jabatan politik yang ada dalam pemerintahan kerajaan atau kesultanan, seperti di Kesultanan Ternate dan wilayah eks kekuasaannya. Seorang jogugu bertugas mewakili raja atau membantu sultan dalam melaksanakan urusan pemerintahan (Mahid, Sadi, Darsono, 2012). Untuk menghindari hegemoni Gorontalo yang telah menjadikan separuh warganya sebagai budak, penguasa Buol menghubungi perwakilan VOC di Ternate.

Pada 1705, atas perintah Gubernur Padtbrugge, VOC mulai mengontrol Buol dengan menempatkan Kopral Jan Blaauw sebagai wakilnya. Hal ini dilakukan karena hasil alam yang melimpah, terutama kayu besi dan kayu lingua yang sangat cocok untuk membuat kapal, rumah, dan benteng pertahanan. Buol kemudian dihubungkan dengan daerah pedalaman Gorontalo dan Sulawesi Tengah melalui jalur laut. Pertumbuhan ekonomi Gorontalo yang kian meningkat selama pertengahan kedua abad XIX, mendorong Buol untuk lebih intensif berinteraksi dengan Gorontalo dibanding dengan Sulawesi Tengah. Pada akhir abad XIX, Buol berada di bawah Afdeeling Gorontalo (Nadjamudin 2016:350). Berdasarkan keputusan pemerintah tanggal 17 April 1889 No. 9 tentang reorganisasi pemerintahan di Sulawesi Utara, maka Kerajaan Gorontalo, Limboto, Bone, dan Boalemo dihapus dan keempat wilayah 
kerajaan ini diletakkan di bawah pemerintahan langsung Hindia Belanda. Pemerintah kemudian membentuk Afdeeling Gorontalo di bawah seorang asisten residen. Asisten residen ini dibantu oleh seorang controleur yang berkedudukan di Limboto. Reorganisasi kembali dilakukan pada 1908, afdeeling ini dibagi menjadi empat onderafdeeling. Salah satunya adalah Buol yang berkedudukan di Paleleh. Onderafdeeling ini membawahi seluruh daerah Buol (Juwono dan Hutagalung, 2005:331-346).

Pada 1956, wilayah ini "dipindahkan" menjadi bagian dari Kabupaten Donggala. Tiga tahun kemudian, terbentuklah Kabupaten Buol Tolitoli yang meliputi bekas wilayah Swapraja Tolitoli dan Swapraja Buol. Pada masa awal itu, Buol sangat berkontribusi besar terhadap perubahan Sulawesi Tengah. Beberapa orang Buol menjadi pemegang kekuasaan di daerah tersebut, seperti Rajawali Muhammad Pusadan sebagai Bupati Kabupaten Sulawesi Tengah dan A. J. Binol sebagai Ketua DPRD Kabupaten Sulawesi Tengah. Hanya tiga dekade saja (1969-1999), Buol menjadi bagian dari Kabupaten Tolitoli. Namun, ketergantungan terhadap Tolitoli masih tetap terasa.

Kondisi alam Buol sangat cocok untuk ditanami kelapa. Tanahnya subur akibat limpahan abu vulkanik dari letusan Gunung Colo di Pulau Unauna (Kepulauan Togean) pada 1893 dan 1983. Kelapa sangat cocok dengan tanah yang berdekatan dengan air mengalir, seperti sungai, pematang sawah, dan tepi pantai berpasir karena air yang bergerak itu mengandung zat asam dan oksigen. Tanaman tropis ini dapat ditemui pada dataran rendah luas yang berada di ketinggian antara 1-200 mdpl. Bahkan masyarakat masih membudidayakan kelapa pada ketinggian 400 mdpl. Pertumbuhannya pun masih sangat baik (Soetedjo, 1969:22). Selain kategori tanah seperti di atas, kelapa dapat tumbuh subur di tanah vulkanik yang landai, tanah gambut, tanah lempung, dan tanah kapur selama tanah tersebut memiliki penyaliran (pembuangan air) yang cukup dan teraerasi (sirkulasi oksigen pada air) yang baik. Jika tanah itu sering mengalami kekeringan, maka kondisi tersebut memengaruhi pembentukan daun dan bunga (Whitten, Mustafa, Henderson, 1987:653).

Pada bagian utara wilayah Buol terdapat Laut Sulawesi yang memberi pengaruh terhadap kondisi alam di pesisir pantainya. Wilayah Buol memang tidak berhadapan langsung dengan Laut Sulawesi, tetapi masyarakat di wilayah ini dapat merasakan manfaatnya. Paling tidak dalam perputaran musim di wilayah tropis (Lapian, 2009:29).

Masyarakat Buol saat ini berasal dari berbagai etnis, seperti Buol, Gorontalo, Bugis, Kaili, Bolaang, Minahasa, Sangir, Lombok, Flores, Jawa, dan Sunda. Mereka menggunakan bahasa Buol yang dituturkan dari mereka yang bermukim di Malangato-Lakuan. "Penduduk Buol merupakan masyarakat pemakai bahasa Buol yang sampai dewasa ini hanya mempunyai satu dialek. ... dengan demikian bahasa Buol kurang mendapat pengaruh dari luar." (Garancang, Kadir, Kajia, dan Mahmud, 1986). 
Dari tahun ke tahun, penduduk Buol mengalami peningkatan. Salah satu penyebabnya adalah migrasi penduduk daerah Gorontalo dan Bugis. Orang Bugis yang bermigrasi melalui pelayaran dan perdagangan bermukim di bagian timur Sungai Buol. Pada awal abad XX, ribuan orang Bugis menetap dan melakukan budi daya kelapa di dataran pantai, yang kemudian wilayah ini berkembang dan dikenal dengan sebutan Kampung Bugis. Pada 18801915, wilayah Kampung Bugis menjadi pusat perdagangan di Buol. Selain beras, komoditas perdagangan paling utama adalah kopra yang diangkut dengan kapal schoener atau kapal kayu Bugis. Komoditas kopra dikirim ke Jawa sampai ke Singapura. Budi daya kelapa di Buol juga semakin marak setelah produksi pertambangan emas di Paleleh mengalami penurunan. Penduduk yang meninggalkan tambang-tambang emas kemudian beralih ke sektor pertanian.

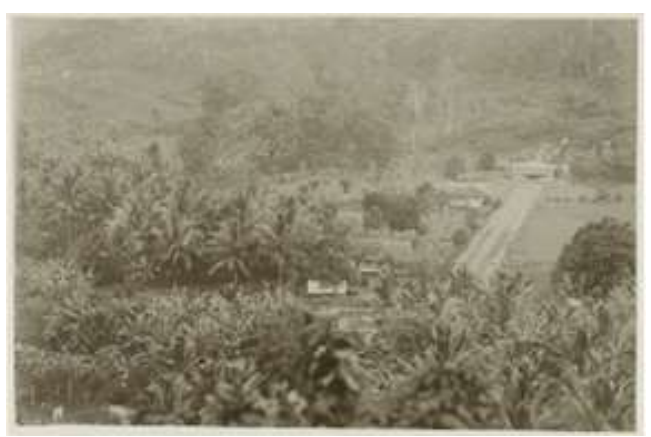

Gambar 1. Jalan ke rumah pejabat administrasi Buol, 1914. Sumber: KITLV 26312.

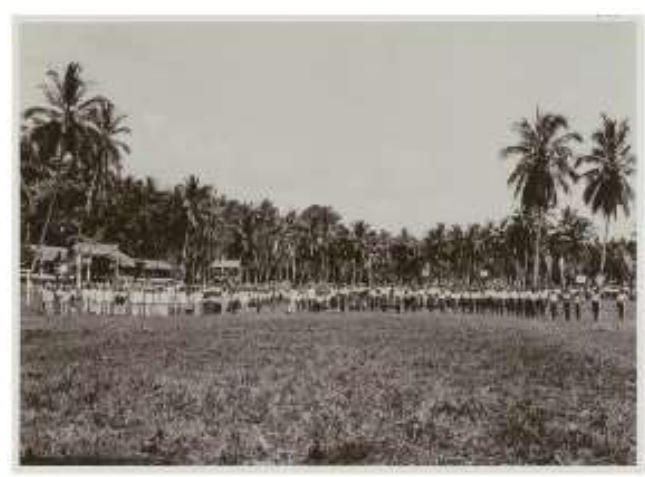

Gambar 2. Perayaan di Buol, 1926. Sumber: KITLV 27771.

\section{Sejarah dan Budi Daya Kelapa di Buol}

Tanaman kelapa sudah lama dikenal dan dimanfaatkan oleh manusia. Namun demikian, asal-usulnya masih diperdebatkan karena hampir setiap tempat mempunyai cerita rakyat mengenai kelapa. Tanaman ini tumbuh di wilayah yang beriklim tropis dan khususnya daerah dekat pantai. Penduduk Karesidenan Manado mulai ikut membudidayakan kelapa sejak 1870 -an. Ada dua afdeeling yang paling awal membudidayakan kelapa, yaitu Minahasa dan Gorontalo. Buol menjadi bagian dari Afdeeling Gorontalo sampai 1956 (Ulaen, 2018:39).

Masyarakat Buol menyebut kelapa dengan sebutan bongo yang juga merupakan salah satu nama desa di Kecamatan Bokat. Selain itu, terdapat beberapa penyebutan yang berhubungan dengan kelapa, di antaranya adalah buti (kelapa sangrai), moagu (kelapa tak berminyak), temad (kelapa bentuk lonjong), tama (kelapa kenari), bvungano (buah kelapa), gieno (lidi kelapa), botang (batang kelapa), minak (minyak kelapa), moganggu (kelapa kering/kopra) (Mailili, 2009:26). 
Buah kelapa, yang mulanya adalah "benda asing", ditemukan oleh Tang dan Bee, sepasang suami istri yang tinggal di Bokat. Tang menyadari bahwa buah kelapa yang ditemukannya tersebut mampu mengubah jalannya sejarah. Bersama istrinya, ia melakukan pembibitan, pembudidayaan, dan pemanenan kelapa. Salah satu komponennya adalah kopra yang menjadi komoditas pasar dunia. Penggunaan laut sebagai sarana pengangkut kelapa oleh Tang dan Bee membuktikan perannya sebagai kata-lisator dalam sejarah Buol (Mailili, 2016:26). Banyak cerita rakyat yang menjadikan laut sebagai elemen utama dalam proses kedatangan orang asing di Buol (Samad, 2002:7).

Kelapa mulai dikenal sejak abad XVII dan puncaknya terjadi ketika kelapa makin populer menjelang periode akhir abad XIX. Paleleh dikenal sebagai salah satu daerah yang mempunyai areal kebun kelapa yang cukup luas. Namun, di akhir abad XIX, perusahaan-perusahaan tambang mulai masuk ke Buol untuk mengeksplorasi emas di Matinan dan Lintidu (Nadjamudin, 2016). Eksistensi tambang tidak berlangsung lama. Pada 1917 mulai terjadi penurunan produksi. Perlahan lubang-lubang tambang itu ditinggalkan. Masyarakat Buol kembali ke kebun kelapa mereka.

Pada 1969, pemerintah mencanangkan program budi daya kelapa. Petani pun berbondong-bondong meremajakan kelapa mereka masingmasing. Masyarakat meremajakan atau mengganti tanaman dengan tunas kelapa yang baru. Antara 1970-1977, banyak sekali lahan yang ditumbuhi kelapa, umumnya pohon kelapa yang masih muda. Ini pemandangan yang terlihat dari Malangato di Paleleh sampai Lakuan Buol di Lakea. Semangat membudidayakan kelapa disebabkan oleh beroperasinya lima koperasi kopra yang bertugas membeli kopra dengan harga yang sesuai ketentuan agar tidak merugikan petani. Adanya usaha mengontrol harga kopra memberi nilai lebih bagi pendapatan masyarakat. Hal ini lantas memicu adanya ekstensifikasi, yakni pembukaan lahan baru guna menambah luas areal tanaman kelapa di Buol. Ekstensifikasi tidak hanya dilakoni petani saja, tetapi juga pemilik modal, pedagang, pemilik toko kelontong, dan aparatur sipil negara. Pembukaan lahan baru yang dilakukan saat itu menyebabkan peningkatan produksi. Kelapa solo adalah varietas yang banyak ditanam petani. Bibit didapatkan petani dengan membeli, pemberian petani lain, dan dari hasil sewa panen kelapa. Mereka lantas melakukan pembibitan sendiri. Bibit-bibit itulah yang ditanam di lahan baru atau untuk mengganti tanaman kelapa yang sudah tua dan tidak produktif lagi. Kelapa Buol telah berbuah pada usia lima tahun. Pada usia 10-50 tahun adalah masa "keemasan" pohon kelapa di Buol. Setelah itu, terjadi penurunan produksi hingga pohonnya mati.

Budi daya kelapa ini lantas mengilhami Muhammad Thamrin Kilat menciptakan lagu Moniayugo Bongo (Peremajaan Kelapa) pada 1991. Jika memperhatikan lirik lagu tersebut, ada empat hal yang disampaikan, yaitu hamparan kelapa, negeri kelapa, bekerja (bersama), dan adanya harapan di masa 
Handep Jurnal Sejarah dan Budaya Vol. 5, No. 1, Desember 2021, hlm. 27-48

depan. Berikut ini adalah lirik lagu tersebut.

\section{Lipuno Buoyo totonon lipuku}

Negeri Buol itulah negeriku

Bulid agu lemba

Gunung dengan lembah

Puli-pulingo bongo

Penuh dengan kelapa

Tia-tiano kekayaanio

Itulah kekayaannya

Sambe tinauguyo buoyo

Sampai negeri Buol punya nama

Duunon kito mokareja titinggai

Marilah kita bekerja bersama-sama

Moniayungo bongo noyayugon

Menanam/mengganti pohon kelapa

yang sudah tinggi

Dugnge pinomuyo yau-yaudun

Tambah tanaman yang sudah ada

Kito tataapo mosanaango

Kita tetap senang

Pada 1992-1998, petani di Buol kembali melakukan peremajaan kelapa. Ada juga yang membuka lahan baru atau memanfaatkan lahan tidur. Hal ini dipicu oleh jatuhnya harga cengkeh akibat kebijakan monopoli perdagangan cengkeh dalam negeri melalui Badan Penyanggah dan Pemasaran Cengkeh (BPPC). Harga cengkeh hanya Rp2.000,00-Rp3.000,00 per kilogram di tingkat petani. Akibatnya, pohonpohon cengkeh di daerah-daerah penghasil utama, salah satunya Buol di Provinsi Sulawesi Tengah, ditebangi atau dibiarkan telantar (Topatimasang, 2013:4). Selain itu, pembukaan lahan perkebunan kelapa juga terjadi di wilayah transmigrasi, seperti di Duamayo, Bokat IV, Langudon, dan desa-desa lainnya di Kabupaten Buol. Perluasan areal tanam pada masa ini berpengaruh terhadap peningkatan produksi pada tahun 2000-an.

Diagram berikut menunjukkan luas areal kelapa di Kabupaten Buol selama periode 1999-2018. Hal yang menarik dari diagram tersebut ialah adanya penurunan drastis pada 2001 dan 2006. Penurunan luas areal tanam kelapa, pada 2001 terjadi karena adanya praktik alih fungsi lahan dari kebun kelapa menjadi kelapa sawit. Kelapa sawit mulai dibudidayakan sejak 1994. Pada saat itu terjadi pembukaan lahan besar-besaran di Buol. Awal abad XXI, sawit menjadi primadona di kabupaten tersebut. Hal inilah yang memengaruhi petani kelapa melakukan alih fungsi lahan mereka. Begitu juga yang terjadi pada 2006, alih lahan kembali terjadi yang mengakibatkan luas areal tanaman kelapa menjadi berkurang. Penurunan ini terjadi karena pelaporan jumlah luas lahan kelapa maupun kelapa sawit di tingkat desa tidak disampaikan ke jenjang yang lebih tinggi. Setelah itu, luas areal tanaman kelapa mengalami peningkatan terus menerus. Pembukaan lahan baru dilakukan untuk mengganti lahan yang telah dikonversi ke tanaman kelapa sawit. Bahkan beberapa lahan tidur ditanami kembali dengan kelapa.

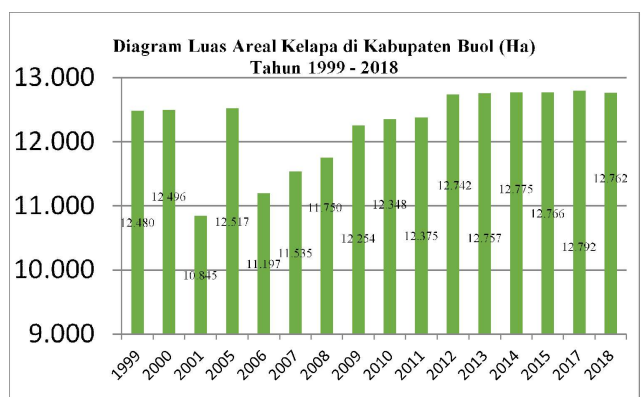

Gambar 3. Luas areal kelapa di Kabupaten Buol (Ha) tahun 1999-2018. Sumber: diolah dari BPS 2002, 2008, 2014, dan 2020. 
Luas perkebunan kelapa di Buol (12.762 ha) hanya sekitar enam persen dari areal perkebunan kelapa di Sulawesi Tengah (214.995 ha). Berdasarkan statistik perkebunan Indonesia, jumlah petani kelapa di Sulawesi Tengah adalah 109.707 Kepala Keluarga (KK). Dari jumlah tersebut, petani kelapa di Buol sekitar 6,7 persen atau 7.375 KK. Jika dibuat rata-rata, maka setiap KK petani di Buol memiliki lahan seluas 1,7 ha. Petani di Buol tidak menghitung luas lahan dengan menggunakan ukuran hektare (ha), tetapi dengan jumlah pohon kelapa. Dari jumlah pohon kelapa tersebut terlihat variasi yang jelas dari kepemilikan lahan. Ada petani yang hanya mempunyai 30 pohon kelapa. Ada pula petani yang memiliki 50-100 pohon. Jumlah yang paling banyak disebutkan adalah antara 100-300 pohon. Jumlahnya lebih banyak dari mereka yang memiliki 300-500 pohon. Ada segelintir orang yang memiliki ribuan pohon. Jarak tanaman kelapa di Buol antara 7-9 meter. Jadi, pada satu hektare tanah terdapat sekitar 121 pohon untuk jarak 9 meter, 154 pohon untuk 8 meter, dan 196 pohon untuk jarak 7 meter. Umumnya, jarak antarpohon adalah 9 meter. Jarak ini dianggap paling ideal untuk tanaman kelapa agar daunnya tidak saling mengganggu antara satu dengan lainnya. Berikut ini gambaran luas areal dan produksi kelapa dalam perkebunan rakyat menurut kabupaten/kota di Sulawesi Tengah.

\begin{tabular}{|l|l|l|}
\hline $\begin{array}{l}\text { Kabupaten/ } \\
\text { Kota }\end{array}$ & $\begin{array}{l}\text { Luas } \\
\text { Area } \\
\text { (Ha) }\end{array}$ & $\begin{array}{l}\text { Produksi } \\
\text { (Ton) }\end{array}$ \\
\hline Banggai Kep. & 20.044 & 10.033 \\
\hline Banggai & 56.275 & 48.262 \\
\hline Morowali & 3.261 & 1.176 \\
\hline Poso & 5.081 & 4.219 \\
\hline Donggala & 28.116 & 28.455 \\
\hline Toli-toli & 20.380 & 14.323 \\
\hline Buol & 12.762 & 10.164 \\
\hline $\begin{array}{l}\text { Parigi } \\
\text { Moutong }\end{array}$ & 29.479 & 36.130 \\
\hline Tojo Una-Una & 22.797 & 31.946 \\
\hline Sigi & 6.037 & 2.516 \\
\hline Banggai Laut & 9.411 & 1.981 \\
\hline $\begin{array}{l}\text { Morowali } \\
\text { Utara }\end{array}$ & 901 & 389 \\
\hline Palu & 452 & 186 \\
\hline Jumlah & $\mathbf{2 1 4 . 9 9 5}$ & $\mathbf{1 8 9 . 7 8 0}$ \\
\hline
\end{tabular}

Tabel 1. Luas areal dan produksi kelapa dalam perkebunan rakyat di

Sulawesi Tengah menurut kabupaten/kota tahun 2018. Sumber: diolah dari data (Hendarwati, Demitria Dewi, 2016).

Petani umumnya melakukan pembibitan sendiri. Pengetahuan mengenai hal itu diwariskan sejak anak-anak oleh orang tua mereka. Salah satu hal yang harus diperhatikan petani dalam pembibitan adalah kualitas bibit. Hal ini tergantung pada mutu pohon induk. Idrus A Ambololong, Kepala Desa Kantanan, pada 20 Maret 2020 mengatakan bahwa pohon induk yang baik adalah kelapa yang telah berusia lebih dari dua puluh tahun, berdaun lebat, tampak hijau, buahnya banyak dan besar, serta pokok pohonnya juga besar. Ciri lain yang perlu diperhatikan adalah buah yang dihasilkan setiap tahun, nilai kopranya tinggi, memiliki kekebalan terhadap serangan hama dan penyakit, batang tumbuh tegak lurus, tandan buah bersandar pada pangkal 
Handep Jurnal Sejarah dan Budaya Vol. 5, No. 1, Desember 2021, hlm. 27-48

(pelepah) daun, dan arah pertumbuhan daun-daun tidak melengkung ke bawah. Setelah pohon induk ditentukan, buah kelapa yang dijadikan bibit adalah buah yang sudah matang di pohon dan berbentuk bulat. Pada setiap tandan, paling banyak hanya ada lima buah yang dapat dijadikan bibit dan tidak boleh dijatuhkan dari atas pohon (Soetedjo 1969:26).

Setelah mendapatkan bibit, tahap selanjutnya adalah persemaian. Bibit disemai dengan cara disimpan di atas tanah yang lembab dan subur, baik di areal perkebunan maupun di pekarangan rumah. Jika membutuhkan bibit dalam jumlah yang banyak, maka petani membuat pagar kawat duri agar tidak diganggu oleh babi hutan, sapi, dan kambing. Selain itu, ada juga yang melakukan persemaian dengan menggantung benih di pohon. Ada juga petani yang langsung menanam bibit di lahan perkebunannya tanpa disemai terlebih dahulu. Bibit kelapa dikupas sedikit tunasnya dan ditanam. Cara seperti ini dianggap lebih cepat karena tidak perlu dipindahkan lagi. Menurut Jamaluddin pada 18 Maret 2020 di Desa Tang, setelah dua bulan tunasnya sudah tumbuh. Tanaman muda perlu perawatan, khususnya saat musim kemarau. Tidak semua tanaman kelapa dapat tumbuh. Oleh karena itu, petani menyiapkan bibit cadangan untuk mengganti tanaman yang mati.

Setelah berumur lima tahun, kelapa mulai berbuah. Banyaknya buah kelapa di setiap pohon tergantung pada kesuburan tanah dan perawatan. Pohon yang baik terlihat dari jumlah buah kelapa yang dihasilkannya setiap tahun. Apabila hasilnya lebih dari 80 butir per tahun, maka disebut kelapa terbaik. Pohon tersebut selalu dijadikan bibit. Jika hanya berkisar antara 60-80 butir, ia disebut kelapa berbuah banyak. Pohon yang berbuah sedang, yakni yang hanya menghasilkan 40-60 butir saja. Jika jumlah buah 20-40 butir, maka dikategorikan berbuah sedikit. Paling fatal jika hanya berbuah antara 1-3 butir (Soetedjo 1969:28). Oleh karena itu, petani di Buol memilih kelapa solo sebagai bibit yang memiliki potensi produksi tinggi dengan karakter unik. Kelapa ini memadukan karakter kelapa dalam dan kelapa genjah. Pada 2013, kelapa solo ditetapkan sebagai kelapa unggul lokal dengan nama Kelapa Buol ST-1. Kelapa Buol ST-1 cepat berbuah, ukuran batang relatif kecil, pertumbuhan tinggi batang lambat, dan ukuran buah relatif besar (Tenda, Tulalo, Kumaunang, Ismail 2014:100).

Budi daya kelapa di Buol dibiarkan tumbuh alami, artinya tanpa pemberian pupuk kimia. Petani hanya memperhatikan soal hama yang menyerang kelapa, seperti sapi, kambing, dan babi hutan. Agar tanaman kelapa terhindar dari serangan babi hutan, petani menyiasatinya dengan melilitkan ban sepeda ke pokok kelapa. Babi hutan mengira ada ular dan menghindari kebun tersebut. Siasat ini tidak berlaku untuk sapi dan kambing. Petani biasa membersihkan mahkota daun saat panen. Pada 2004, hama menyerang kelapa di Buol sehingga produktivitasnya menurun saat itu. Pada musim kemarau, produksi kelapa juga mengalami penurunan. Issuarno Gobel, petani kelapa di Desa Bukamog, pada 30 Maret 2020 mengatakan bahwa pohon kelapa sebanyak 300 batang 
yang berada di depan rumahnya hanya menghasilkan 7.000 buah karena musim kemarau. Jika dirata-ratakan, hasil per pohon adalah sekitar 23 buah. Ini berarti sangat kurang.

Panen kelapa merupakan kegiatan penting dalam proses produksi. Petani di Kecamatan Bokat memetik buah kelapa dengan cara memanjat menggunakan tali sebagai pijakan. Pada 1980-an, pemetik (masyarakat Buol menyebutnya tukang panjat kelapa) masih memakai tangga untuk kelapa yang tingginya belum mencapai sepuluh meter. Lebih dari itu, tukang panjat tetap menggunakan tangga, dan dilanjutkan memakai tali. Dalam sehari, mereka dapat memanjat antara 35-50 pohon kelapa. Upah memetik buah kelapa adalah Rp4.000,00Rp5.000,00 per pohon. Upah tersebut dikatakan murah, berbeda dengan daerah lain yang cenderung mahal atau disesuaikan dengan harga kopra di daerah itu. Di Minahasa, upah memanjat pada 2017 adalah Rp6.000,00 (Purba 2017: 55).

Beberapa tukang panjat belajar memetik buah kelapa dari orang tuanya. Sebagian lagi karena dipaksa oleh tuntutan ekonomi. Tidak hanya keterampilan memanjat saja yang dibutuhkan untuk menjadi seorang tukang panjat handal, tetapi juga soal (kekuatan) fisik yang harus dilatih agar tubuh terbiasa dengan kondisi, posisi, dan keadaan batang kelapa. Seorang tukang panjat juga harus melatih mentalnya agar tidak mudah terkejut dan panik, sehingga bisa tetap fokus dan terjaga konsentrasinya selama bekerja. Fokus dan konsentrasi adalah syarat mutlak dalam pekerjaan penuh risiko ini. Menurut Idrus A. Ambololong di Desa Kantanan pada 20 Maret 2020, sudah banyak korban yang umumnya meninggal dunia karena terjatuh.

Tidak semua desa memiliki tukang panjat kelapa, tetapi ada juga desa yang surplus tenaga kerja. Desa Bongo, Kecamatan Bokat, sebagai contoh, mempunyai sembilan orang tukang panjat kelapa. Salah seorang di antaranya adalah Mardi, 58 tahun, yang bekerja sejak 20 tahun lalu. Ia belajar dari orang tuanya. Mardi bekerja hampir setiap hari. Tidak hanya di desanya (Bongo), tetapi juga di Desa Doulan dan Bukamog. Setelah sebulan rutin bekerja, Mardi beristirahat dua bulan, sambil menunggu permintaan dari pemilik kebun untuk memetik buah kelapa kembali. Selama masa istirahat, ia bekerja menanam bawang merah di kebun miliknya.

Begitu juga dengan Salim, tukang panjat asal Desa Tang berusia 54 tahun. Desanya mempunyai tiga orang tukang panjat aktif. Semuanya berusia di atas 40 tahun. Salim sudah memanjat kelapa lebih dari 20 tahun. Salim memutuskan untuk menggeluti profesi ayahnya itu demi kehidupan ekonomi keluarganya. Ketika masih muda, dia mampu memanjat 40-50 pohon. Ia juga sering memanjat kelapa di Desa Doulan dan Bokat. Aktivitas tersebut dilakukannya setiap hari, kecuali hari Jumat. Salim juga bekerja di kebun miliknya di selasela kegiatannya itu.

Samsuddin, petani kelapa, yang memiliki 200 pohon kelapa, mempekerjakan dua orang tukang panjat selama tiga hari. Semakin banyak jumlah pohon kelapa, makin banyak pula tukang panjat yang dibutuhkan. 
Handep Jurnal Sejarah dan Budaya

Umumnya para tukang panjat itu sudah bergerak ke kebun kelapa setelah subuh. Mereka bekerja hingga pukul 09.00 atau 10.00. Waktu berhenti memanjat kelapa juga dapat ditentukan oleh target jumlah pohon yang hendak diselesaikan. Jika menargetkan 30 pohon, maka ketika mencapai angka tersebut, ia pun berhenti. Mereka bekerja sekitar 3-5 jam sehari. Pada bulan puasa, beberapa tukang panjat bekerja memanjat kelapa pada dini hari, sekitar pukul 02.00 hingga 04.00, dengan menggunakan senter sebagai penerang. Salim, seorang pemanjat kelapa di Desa Tang, pada 15 Maret 2020 mengatakan bahwa pemanjat dibantu orang lain dari bawah pohon untuk menyenter kelapa yang akan dipetik.

\section{Pemasaran Kopra Di Buol}

Sudah lebih dari seabad lamanya, petani di Buol hanya mengolah buah kelapa menjadi kopra saja sebagaimana tradisi leluhur mereka. Buah kelapa diolah menjadi kopra dengan cara diasapi atau dipanggang bara api. Pengeringan kopra dengan metode seperti itu menjadi pilihan karena prosesnya yang mudah, ringan, dan tidak menggunakan teknologi canggih. Kopra dapat dihasilkan dengan cepat hanya bermodalkan tenaga dan juga bantuan tenaga hewan (sapi untuk menarik gerobak), serta alat-alat kerja sederhana (Notowerdojo 1943:27).

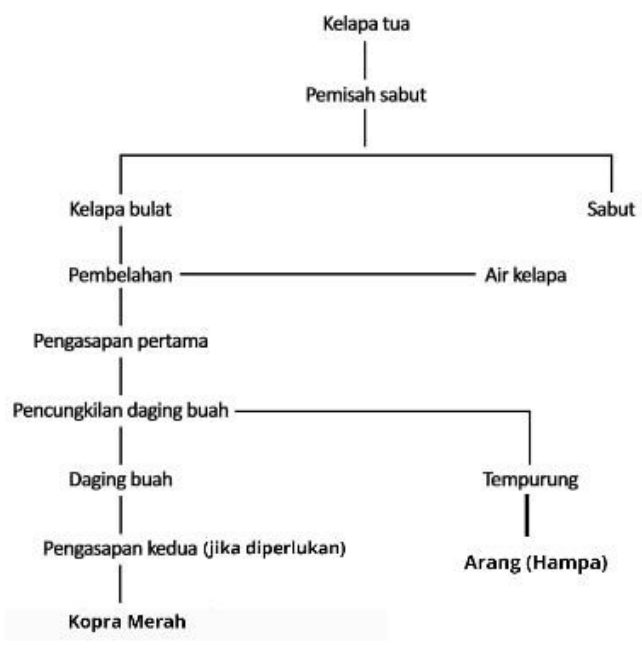

Gambar 4. Diagram pembuatan Kopra di Buol. Sumber: diolah dari hasil penelitian lapangan di Buol, Maret 2020.

Mengeringkan kopra dengan cara diasapi hanya menghasilkan kopra merah atau campuran dan kopra afkir. Ada empat macam kopra, yaitu kopra kering mati, kopra kering untuk ekspor, kopra sehari-hari, dan kopra basah (Notowerdojo 1943:7). Kopra campuran (Indonesia) berasal dari berbagai jenis kelapa. Kopra tersebut dikategorikan ke dalam tiga kualitas, yaitu kualitas A (kopra dengan komposisi air maksimal 5 persen, lemak maksimal 65 persen, dan asam lemak bebas maksimal 2 persen), kualitas B (kopra dengan komposisi air maksimal 5 persen, lemak maksimal 60 persen, dan asam lemak bebas maksimal 2 persen), dan kualitas C (kopra yang tidak layak jual atau tidak memenuhi syarat kualitas A dan B) (Lembaga Penelitian dan Pendidikan Industri Departemen Perindustrian 1975:1). Sementara Awang (1994:89) mengategorikan kopra berdasarkan cara pengeringannya. Pertama, smoked dried copra yang dikeringkan dengan 
panas buatan. Biasanya berbau asap dan berwarna coklat sampai kelabu hitam. Kopra ini biasa disebut fair merchantable (fm). Kedua, kopra yang dikeringkan tanpa melalui kontak langsung dengan sumber panas. Hasilnya, kopra berwarna putih yang disebut fair merchantabe sundried atau supergrade copra. Kopra jenis ini baru saja diuji coba di Desa Bongo Kecamatan Bokat Kabupaten Buol pada 2019. Peluang ekonominya cukup besar dan dapat dijadikan sebagai produk unggulan karena memiliki pasar sendiri. Harga kopra putih biasanya jauh lebih tinggi.

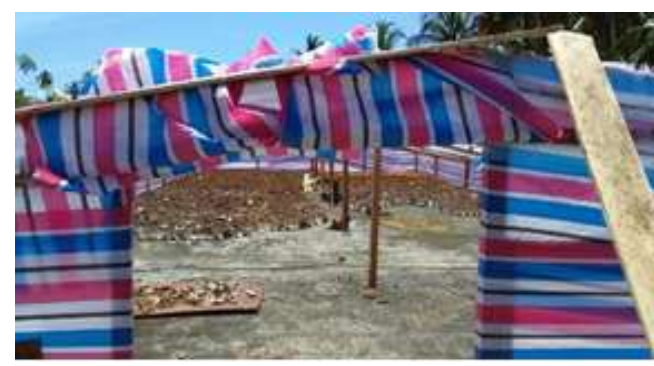

Gambar 5. Pengolahan daging kelapa untuk pembuatan kopra putih di Desa Bongo Sumber: dokumentasi penulis.

Buol memiliki potensi kopra yang sangat menjanjikan. Sayangnya, produksi kopra Buol memberi pengaruh yang kecil terhadap hasil produksi kopra di Sulawesi Tengah, yakni 8,8 persen (sebagai yang tertinggi) pada 2005 dan 3,08 persen (sebagai angka terendah) pada 2000. Kelapa dan kopra adalah sumber ekonomi paling berpengaruh dalam kehidupan ekonomi masyarakat Buol. Berikut ini tabel mengenai jumah produksi kopra di Buol dan Sulawesi Tengah (1999-2019).

\begin{tabular}{|l|c|c|c|}
\hline Tahun & $\begin{array}{c}\text { Kopra } \\
\text { Buol }\end{array}$ & $\begin{array}{c}\text { Kopra } \\
\text { Sulteng }\end{array}$ & $\begin{array}{c}\text { Rasio } \\
\text { B:ST }\end{array}$ \\
\hline 1999 & 5.565 & 177.392 & 3,14 \\
\hline 2000 & 5.570 & 180.683 & 3,08 \\
\hline 2001 & 6.416 & 183.028 & 3,51 \\
\hline 2002 & na & 205.242 & na \\
\hline 2003 & 12.538 & 199.695 & 6,28 \\
\hline 2004 & 7.506 & 189.168 & 3,97 \\
\hline 2005 & 15.882 & 180.388 & 8,80 \\
\hline 2006 & 16.022 & 187.491 & 8,54 \\
\hline 2007 & 15.137 & 186.753 & 8,10 \\
\hline 2008 & 15.279 & 206.958 & 7,38 \\
\hline 2009 & $15.295,20$ & 225.541 & 6,69 \\
\hline 2010 & $15.490,40$ & 202.384 & 7,65 \\
\hline 2011 & na & 192.469 & na \\
\hline 2012 & 12.742 & 218.411 & 5,83 \\
\hline 2013 & 12.757 & 189.572 & 6,72 \\
\hline 2014 & 12.775 & 190.568 & 6,70 \\
\hline 2015 & na & $167.172,07$ & na \\
\hline 2016 & 12.766 & $184.486,51$ & 6,92 \\
\hline 2017 & na & $187.404,30$ & na \\
\hline 2018 & 10.166 & 193.885 & 5,24 \\
\hline 2019 & 10.164 & 189.661 & 5,36 \\
\hline
\end{tabular}

Tabel 2. Produksi Kopra di Buol dan

Sulawesi Tengah 1999-2019 (dalam ton).Sumber: diolah dari data BPS 2002, 2008, 2014, dan 2020.

Terdapat tiga periode penting ketika mengamati peran penting kopra dalam ekonomi masyarakat di Buol. Periode pertama, yaitu pada 1999-2003, di mana hasil produksi kopra meningkat. Pada periode tersebut, terjadi peningkatan produksi walau tidak signifikan. Kecuali pada 2003, jika dibandingkan pada 2001, terjadi peningkatan hingga mencapai 6.122 ton. Padahal pada 2000-2001, jumlah produksi hanya meningkat sebanyak 846 ton saja. Ini membuktikan bahwa hasil dari peremajaan antara 1990-1998 telah dinikmati oleh petani. Menurut Musa D. Abdullah dan Haslani di Bokat pada 30 Maret 2020, saat itu terjadi pembukaan kebun kelapa baru di lereng-lereng bukit atau dataran rendah di pedalaman. Eskor Ton, Kepala Desa Duamayo, pada 18 Maret 
2020 mengatakan bahwa pada 1996, penduduk transmigran dari berbagai wilayah didatangkan ke Buol. Banyak di antara mereka menanam kelapa dan telah berbuah.

Periode kedua, yaitu antara 20032010, produksi kopra meningkat, kemudian stabil. Pada 2004 sempat terjadi penurunan yang tajam, yakni dari angka 12.538 ton (2003) menjadi 7.506 ton (2004). Tahun berikutnya mengalami peningkatan sebanyak 8.376 ton. Terus bertambah 140 ton hingga mencapai jumlah sebanyak 16.022 ton pada 2006. Pada 2007 mengalami penurunan sebanyak 885 ton. Setelah itu, mengalami peningkatan dalam jumlah kecil. Pada 2004, hama menyerang kelapa di Buol. Para petani mengingatnya sebagai sesuatu yang tampak biasa saja, tetapi membuat kelapa sulit berproduksi. Akan tetapi, tidak semua kawasan terkena serangan hama. Hanya wilayah Bokat, Bukal, Momunu, dan Bunobogu. Antara 20052010, terjadi kestabilan produksi kopra, walaupun terdapat penurunan sebanyak 885 ton pada 2007. Kestabilan hasil produksi ini disebabkan karena keberadaan kelapa hasil peremajaan dan ekstensifikasi pada periode 1992-1998, yang telah berada pada puncak produksinya (BPS 2008).

Periode ketiga berlangsung antara 2010-2019, ketika penurunan produksi kopra terjadi terus menerus. Pada 20052008, kelapa sawit menjadi tren. Banyak petani yang melakukan konversi lahan kelapa (kelapa dalam) menjadi kelapa sawit. Tiga tahun pertama begitu menjanjikan. Namun setelah itu, keadaan menjadi tidak menentu. Perusahaan mulai abai terhadap petani plasma, yakni mereka yang memiliki lahan kebun kelapa sawit yang dibangun oleh sebuah perusahaan (inti), sebagai bentuk kerja sama kemitraan antara perusahaan tersebut dengan masyarakat sekitar perkebunan (Asik 2017:852). Harga buah kelapa sawit hanya Rp600 per kilogram. Ini setengah dari harga yang telah ditetapkan. Pembayarannya pun selalu tersendat. Oleh karena itu, banyak petani kelapa sawit di Buol yang menjual (buah) hasil panen mereka ke Mamuju Utara. Persoalan lain adalah runtuhnya hegemoni koperasi kopra yang telah berubah menjadi Koperasi Unit Desa (KUD) terhadap tata niaga kopra di Buol. Salah satu koperasi yang mengalami hal tersebut adalah KUD Akrab yang berasal dari koperasi kopra, yang didirikan pada 1969. Koperasi ini berubah status pada 1994. Pada 2002, KUD Akrab, dengan alasan mengem-bangkan usaha, mulai merambah ke berbagai jenis usaha guna mempertahankan kondisi keuangan koperasi. Akhirnya pada 2012, KUD Akrab pun mati suri.

Jika memperhatikan tabel produksi kopra Sulawesi Tengah, terdapat tiga periode penting, yaitu masa peningkatan produksi (1999-2002), masa penurunan produksi (2002-2005), dan masa fluktuasi (2005-2019). Masa peningkatan produksi kopra hanya berlangsung tiga tahun saja. Ratarata peningkatan produksi kopra Sulawesi Tengah sebesar 9,3 ton per tahun. Di masa penurunan produksi pada periode 2002-2005, kopra Sulawesi Tengah mengalami penurunan rata-rata 8,3 ton per tahun. Berikut ini merupakan rinciannya. Peningkatan 
produksi kopra Sulawesi Tengah pada 2000 dari tahun sebelumnya, yaitu 3.291 ton. Pada 2001, hanya bertambah 2.345 ton dan kembali melonjak pada 2002 menjadi 22.214 ton. Jika ditotalkan menjadi $27.850 .000 \mathrm{~kg}$, dan apabila dibagi tiga, maka hasilnya adalah 9,3 ton per tahun. Perhitungannya ialah turun 5.547 ton pada 2003 (hasil produksi kopra Sulawesi Tengah), sebanyak 10.527 ton pada 2004, dan sebanyak 8.180 ton setahun setelahnya.

Terakhir, masa fluktuasi. Selama empat belas tahun, fluktuasi hasil produksi hampir terbagi merata dengan perbandingan delapan tahun naik dan enam tahun turun. Walaupun begitu, usaha pembuatan minyak kelapa dan minyak kelapa murni dengan daging buah kelapa sebagai bahan bakunya berjalan lancar dengan baik.

Pada 1980-an, harga kopra itu berkisar antara Rp8.000,00Rp10.000,00 per kuintal. Akhir 1980an, keadaan mulai berubah. Harga kopra naik cukup tajam menjadi Rp65.000,00. Awal 1990-an, sebelum krisis moneter, harga kopra berkisar antara Rp70.000,00-Rp 85.000,00. Saat krisis ekonomi 1997-1998 bahan pangan masih tersedia, namun untuk bahan sandang yang terasa sulit. Kopra ada di pasar, tetapi harganya mahal. Harga kopra pada 1998 sekitar Rp120.000,00. Ketika B.J. Habibie menjadi presiden, harga kopra tiba-tiba melonjak naik, yaitu Rp1.000.000,00 per kuintal. Kenaikan harga ini terjadi dalam waktu singkat. Mahrus Hasan, petani di Desa Tayadun, pada 25 Maret 2020 menyatakan bahwa ia hanya sekali saja merasakan harga seperti itu,
Rp1.120.000 per kuintal. Sementara Thalib, petani kelapa di Desa Tayadun, pada 26 Maret 2020, mengatakan tidak pernah mendapatkannya karena ia baru saja panen. Pada panen berikutnya, harga tersebut sudah turun dari angka satu juta rupiah.

Saat Presiden Abdurrahaman Wahid menjabat, ada harapan kenaikan harga kopra. Masa ini diwarnai dengan berpisahnya Buol dari Kabupaten Buol Tolitoli. Petani berharap agar harga kopra naik lagi, namun yang terjadi adalah penurunan harga. Harga kopra saat itu adalah Rp960.000,00. Tahun berikutnya harga kopra per kuintal turun menjadi Rp840.000,00. Pada 2002, harga kopra masih fluktuatif. Harga tertinggi pada tahun tersebut adalah Rp810.000,00 dan yang terendah Rp750.000,00. Saat situasi seperti itu, KUD-KUD berusaha membantu menstabilkan harga kopra dengan mengambil bagian sebagai pembeli, sekaligus mencari keuntungan. Harga kopra terus mengalami penurunan dari tahun ke tahun. Pada 2009 harga sempat naik sebanyak Rp70.000,00, sebab harga kopra setahun sebelumnya adalah Rp650.000,00 per kuintal dan naik menjadi Rp720.000,00 per kuintal pada tahun berikutnya. Ramli, guru di Kelurahan Biau, pada 29 Maret 2020 mengatakan bahwa kenaikan harga ini menyebabkan petani membeli mesin traktor tangan untuk mempermudah dan mempercepat pengolahan lahan pertanian. Mesin traktor tangan yang disebut dompeng ini dipergunakan sebagai penarik gerobak pengangkut buah kelapa menggantikan peran dan fungsi sapi. 
Perubahan harga kopra ditentukan oleh pasar internasional yang selalu tidak sejalan dengan harapan petani. Oleh karena itu, petani kelapa selalu mengeluhkan harga kopra yang sangat tidak bersahabat dengan mereka dalam rentang enam tahun terakhir di Buol. Keuntungan yang mereka terima terkadang tidak mampu menutupi biaya (sewa) pembuatan kopra, karena kebutuhan keluarga di saat pascapanen sulit terpenuhi bila hanya mengandalkan satu sumber pendapatan saja. Tiga bulan adalah rentang waktu yang singkat bagi petani kaya. Mereka pasti mampu melaluinya tanpa persoalan yang berarti. Hal ini berbanding terbalik dengan keadaan petani kecil, waktu tiga bulan begitu lama. Apalagi ketika mereka tidak memiliki simpanan, maka si petani akan mencari pinjaman guna menutupi biaya hidup keluarganya. Ketika panen, hasilnya menjadi milik pemberi pinjaman. Amin, petani kelapa di Kantanan, pada 4 April 2020, mengatakan bahwa ada juga pemberi pinjaman dengan keringanan untuk mengangsurnya tanpa bunga.

Tinggi rendahnya harga kopra sangat ditentukan oleh permintaan pasar. Akan tetapi, ada empat penyebab tinggi rendahnya harga kopra yang ada di tingkat petani, yaitu praktik ijon, kualitas kopra, jaringan pemasaran yang berlapis; dan tidak adanya koperasi sebagai penyeimbang pasar. Praktik ijon tidak dapat dihindari oleh petani kecil dan mereka yang mempunyai seorang anak yang sedang menempuh pendidikan di perguruan tinggi. Sesekali, bahkan ada yang berkali-kali dalam setahun melakukan praktik tersebut. Agar terhindar dari praktik itu, sistem pertanian monokultur perlu ditinjau kembali agar dapat memenuhi kebutuhan keluarga. Hasil dari kebun kelapa dipergunakan untuk biaya pendidikan anak-anak mereka. Kebun bahan pangan diproyeksikan untuk menutupi kebutuhan sandang, pangan, dan papan. Bila seperti itu, maka hasil kebun kelapa menjadi simpanan ekonomi keluarga.

Harga kopra juga ditentukan oleh kualitasnya. Umumnya petani di Buol tidak memperhatikan kualitas kopra mereka. Petani kelapa di Buol hanya memproduksi kopra kualitas nomor dua saja. Tentu harganya lebih rendah dari kualitas nomor satu. Karena kadar airnya yang masih tinggi, kopra mudah mengalami penyusutan berat yang signifikan. Hal inilah yang selalu dikhawatirkan oleh pedagang pengepul atau pedagang pengumpul di Buol. Cara membuat kopra pada dasarnya hampir sama di seluruh Indonesia. Di Buol sulit menemukan kopra hasil pengeringan sinar matahari atau pengeringan dengan bara api, yang ada adalah kopra mixed atau kopra merah. Inilah yang menjadi dasar para pengepul dan pedagang pengumpul untuk mempermainkan harga kopra.

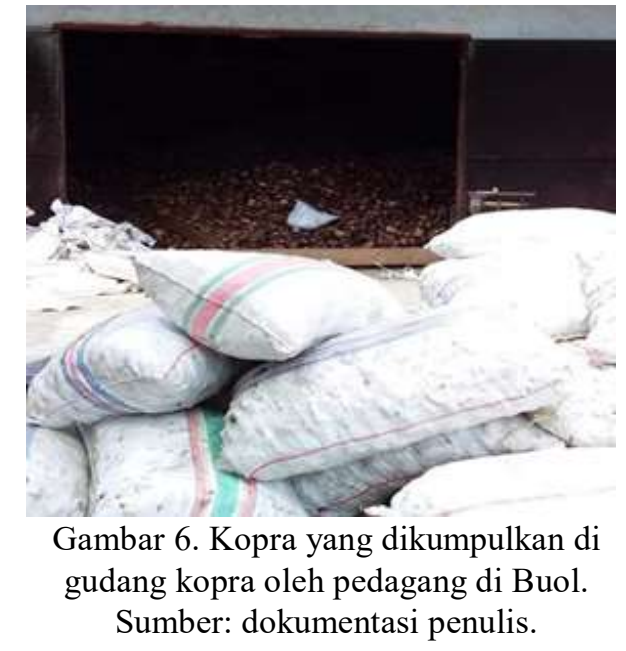


Persoalan lain yang juga penting posisinya adalah jaringan pemasaran. Semakin pendek jaringan pemasaran, maka semakin tinggi harga sebuah komoditas. Jaringan pemasaran di Buol itu hanya terdiri atas tiga sampai empat lapis saja, sebelum hadirnya para pembeli kopra dari Manado pada 2016. Ada dua periode penting yang berkaitan dengan jalur pemasaran kopra di Buol. Pertama, periode sebelum 2003. Kopra dari petani dibeli oleh para pengepul, dengan dua cara, yaitu petani sendiri yang membawa kopranya kepada gudang penampungan milik pengepul atau para pengepul menanti di pasarpasar desa dan petani yang membawa kopra mereka ke pasar. Setelah dari gudang penampungan para pengepul, kopra dikirim ke gudang-gudang pedagang pengumpul yang ada di (Kota) Buol. Dari para pedagang pengumpul inilah, kopra kemudian dikirim kepada para pedagang antarpulau yang ada di Tolitoli maupun Buol. Ada kalanya pedagang pengumpul juga bertindak sebagai pedagang antarpulau. Kopra pun dikapalkan menuju Surabaya sebagai tujuan akhir pemasaran. Kedua, periode 2003-2016. Periode ini ditandai dengan menguatnya para pedagang Tionghoa dalam bisnis kopra di Buol. Penyebabnya adalah mundurnya koperasi-koperasi unit desa, yang sebelumnya adalah koperasi kopra. Jika para petani yang langsung membawa kopra mereka ke pedagang pengumpul, maka para pedagang pengumpul yang selalu menyediakan sarana angkutan untuk mengangkut kopra-kopra tersebut ke gudang penampungan mereka. Lantas kopra dikirim kepada pedagang antarpulau yang ada di Tolitoli maupun di Buol. Ada juga pedagang pengumpul yang mendapat izin untuk menjadi pedagang antarpulau. Pelabuhan Leok di Buol dan Pelabuhan Dede di Tolitoli menjadi pintu keluar kopra Buol menuju Surabaya.

Pada 2016, ada dua perusahaan besar yang bersaing membeli kopra di Buol, yaitu PT Cargil Indonesia yang berpusat di Amurang (Sulawesi Utara) dan PT Berkat Abadi yang berpusat di Tonsea (Sulawesi Utara). Salah seorang karyawan Berkat Abadi mengatakan bahwa perusahaan mereka membeli kopra dari Bukal, Momunu, dan Bunobogu, serta Bokat (khususnya di Kampung Doulan). Perusahaan ini membeli kopra melalui para pengepul maupun pedagang pengumpul yang ada di wilayah tersebut. Sepanjang 20192020 (Maret), harga kopra yang diberikan Berkat Abadi adalah antara Rp5.600,00-Rp7.200,00 per kilogram. Padahal pada tahun-tahun sebelumnya, mereka membeli kopra dengan harga paling rendah sebesar Rp 6.800,00 per kilogram. Sementara, angka tertinggi pada 2016 adalah Rp8.000,00 per kilogram. Setahun setelahnya, harga terendah adalah Rp7.100,00 per kilogram, sedangkan harga tertingginya adalah Rp8.200,00 per kilogram. Pada 2018, harga terendah adalah Rp7.000,00, sedangkan harga tertingginya adalah Rp.8000,00 per kilogram.

PT Cargil Indonesia adalah salah satu perusahaan pembeli kopra yang terkenal di kalangan pengepul dan pedagang pengumpul di Buol. Mereka membeli kopra asalan atau kopra campuran. PT Cargil Indonesia juga 
membuka cabang di Ogoamas, Ampana, dan Palu. Perusahan ini tidak membeli kopra langsung kepada petani, melainkan dari para pedagang pengumpul dengan jumlah minimal $1.000 \mathrm{~kg}$ dalam sekali pembelian. Harga yang ditawarkan biasanya lebih mahal dari Rp200,00-Rp300,00 per kilogramnya, dibandingkan dari yang diberikan Berkat Abadi. Hal ini dilakukan, selain untuk mendapat stok kopra sesuai dengan target perusahaan, juga untuk menstabilkan harga kopra yang sangat fluktuatif. Rendahnya harga di tingkat petani adalah persoalan yang selalu dikeluhkan oleh petani kelapa di Buol. Petani pada dasarnya menunggu kontribusi pemerintah daerah untuk komoditas yang satu ini. Petani berharap agar ada perusahaan daerah yang bekerja seperti koperasi agar dapat menstabilkan harga.

Keberadaan koperasi sangat membantu pemerintah dalam mengendalikan harga komoditas, sekaligus menjadi tempat berlindung rakyat kecil dari jeratan kemiskinan. Koperasi didirikan untuk menjembatani kepentingan ekonomi rakyat, karena pada hakikatnya koperasi bertujuan untuk meningkatkan kesejahteraan anggota sesuai dengan kepentingan usahanya sendiri. Hilangnya koperasi dalam pemasaran kopra di Buol ternyata membawa masalah baru, yakni harga kopra menjadi tidak dapat diatur dan naik-turun sekehendak pasar internasional. Pasar internasional tersebut sebenarnya hanyalah wacana pada pedagang besar yang tetap menginginkan agar pemasaran komoditas ini berada di tangan mereka. Kolapsnya Koperasi Unit Desa (KUD) membuat pemasaran kopra berada di tangan seorang pedagang besar, jelas Suleman Haruna, petani kelapa di Desa Bukamog, pada Maret 2020. Sistem tata niaga kopra menjadi tidak kondusif, bahkan dapat menimbulkan sentimen negatif.

\section{SIMPULAN}

Masyarakat Buol melihat kelapa atau bongo dalam empat sisi, yakni kelapa sebagai simbol ekonomi, identitas negeri, perubahan budaya, dan penanda zaman. Sejak lama, kelapa telah menjadi simbol ekonomi petani di Buol. Lapangan kerja baru sering kali lahir, berkembang, dan hilang. Namun kelapa tetap menjadi pilihan masyarakat untuk menyandarkan harapan ekonomi mereka. Ketika masih menjadi bagian dari Kabupaten Buol Tolitoli, kelapa adalah bagian penting dari sejarah masyarakat di wilayah tersebut, apalagi setelah Kabupaten Buol didirikan. Tanpa disadari, selama ini budi daya kelapa telah menjadi sarana untuk mempertautkan budaya. Selama proses budi daya kelapa, terlihat banyak kebiasaan masyarakat yang berubah. Salah satu yang tampak adalah motorisasi. Pada 2009, mesin traktor mulai menggantikan gerobak sebagai alat pengakut kelapa. Oleh karena itu, dapat dikatakan bahwa kelapa merupakan salah satu penanda zaman di Buol. Hal ini dapat dilihat dari berbagai peristiwa yang terjadi, mulai dari lahirnya koperasi kopra pada 1969, persaingan bisnis antara pedagang lokal dan pedagang Tionghoa, hingga menghasilkan sebutan Cina Hitam pada tahun 1980-an. Era tambang dan kelapa sawit pada dekade kedua abad XXI 
memang tampak menjanjikan, namun usaha di bidang kelapa masih tetap eksis, bahkan memunculkan usaha baru. Pengolahan virgin coconut oil (VCO) dan arang tempurang adalah buktinya.

Kopra tetap menjadi primadona bagi petani kelapa. Akhir 2019, muncullah usaha baru yaitu pembuatan kopra putih yang tentunya bernilai ekonomi tinggi. Keterlibatan negara masih diperlukan guna mengontrol harga di tingkat petani. Produksi bibit berkualitas perlu ditingkatkan dan subsidi kepada petani diberikan secara langsung, tanpa perantara. Petani kelapa harus dilindungi secara utuh, baik dari soal modal usaha hingga soal pemasaran hasil produksi mereka.

\section{DAFTAR SUMBER}

Asba, Abdul Rasyid. 2003. "Ekspansi dan Kontraksi: Ekspor Kopra Makassar, 1883-1958.” Universitas Indonesia.

Asik, Iglesias. 2017. "Program Plasma Perkebunan Kelapa Sawit PT. Rimba Rayatama Jaya dalam Pola Kemitraaan Masyrakat di Kampung Besiq Kecamatan Damai Kabupaten Kutai Barat." EJournal Ilmu Pemerintahan 849-60.

Awang, San Afri. 1994. Kelapa: Kajian Sosial Ekonomi. Yogyakarta: Aditya Media.

BPS. 2002. Kabupaten Buol dalam Angka 2001. Buol: BPS Kabupaten Buol.
BPS. 2008. Kabupaten Buol dalam Angka 2007. Buol: BPS Kabupaten Buol.

. 2014. Kabupaten Buol dalam Angka 2013. Buol: BPS Kabupaten Buol.

2020. Kabupaten Buol dalam Angka 2019. Buol: BPS Kabupaten Buol.

Garancang, Ahmad, Amir Kadir, Dahlan Kajia, dan Zohra Mahmud. 1986. Struktur Bahasa Buol. Jakarta: Departemen Pendidikan dan Kebudayaan.

Hendarwati, Demitria Dewi, ed. 2016. Statistik Perkebunan Indonesia 2015 - 2017 Kelapa. Jakarta.

Henley, David. 2005. Fertility, Food and Fever: Population, Economy and Environment in North and Central Sulawesi, 1600-1930. Leiden: KITLV Press.

Juwono, Harto, dan Yosephine Hutagalung. 2005. Limo Lo Pohalaa: Sejarah Kerajaan Gorontalo. Yogyakarta: Ombak.

Kartodirdjo, Sartono. 2017. Pengantar Sejarah Indonesia Baru: 15001900, dari Emporioum sampai Imperium. Yogyakarta: Ombak.

Lapian, Adrian B. 2009. Orang LautBajak Laut-Raja Laut: Sejarah Kawasan Laut Sulawesi Abad XIX. Depok: Komunitas Bambu.

Mahid, Syakir, Haliadi Sadi, dan Wilman Darsono. 2012. Sejarah 
Handep Jurnal Sejarah dan Budaya Vol. 5, No. 1, Desember 2021, hlm. 27-48

Kerajaan Bungku. Yogyakarta: Ombak.

Mailili, Maryam G. 2016. Cerita Rakyat Buol. Buol: CV Asra Jaya.

Mardiatmoko, Gun, Mira Ariyanti, dan Ronny Loppies. 2011. Produksi Tanaman Kelapa (Cocos Nucifera L.). Ambon: Badan Penerbit Fakultas Pertanian Universitas Pattimura.

Moehar Daniel. 2002. Pengantar Ekonomi Pertanian. Jakarta: Bumi Aksara.

Nadjamudin, Lukman. 2016. "History of Buol: Study on the Border Territory and Exploitation of Mine." 1st UPI International Conference on Sociology Education, UPI ICSE.

Notowerdojo, Moertedjo. 1943. Kopra. Djakarta: Balai Poestaka.

Samad, A. Rahim. 2002. Sejarah Buol Jilid 1. Palu: Perum PNRI.

Soetedjo, R. 1969. Ilmu Bercocok Tanam Kelapa. Djakarta: C.V. Yasaguna.

Tenda, Elsje T., Meity A. Tulalo, Jeanette Kumaunang, dan D. A. N. Ismail. 2014. "Keunggulan Varietas Kelapa Buol ST-1 dan Potensi Pengembangannya." Buletin Palma 15(2):93-101.

Topatimasang, Roem. 2013 . "Pengantar, Cengkeh: Dulu, Kini \& Nanti." dalam Ekspedisi Cengkeh.
Makassar: Ininnawa dan Layar Nusa.

Ulaen, Alex John. 2018. Dari Landstreek van Manado ke Otonomi Daerah: Teritorialisasi dan Identifikasi-Etnis. Yogyakarta: Amara Books.

Whitten, Anthony J., Muslimin Mustafa, dan Gregory S. Henderson. 1987. Ekologi Sulawesi. Yogyakarta: Gadjah Mada University Press.

Wawancara. Amin. Desa Kantanan, 4 April 2020.

Wawancara. Eskor Ton. Desa Duamayo, 18 Maret 2020.

Wawancara. Haslani. Bokat, 30 Maret 2020.

Wawancara. Idrus A Ambololong. Desa Kantanan, 20 Maret 2020.

Wawancara. Issuarno Gobel. Desa Bukamog, 13 Maret 2020.

Wawancara. Jamaluddin. Desa Tang, 18 Maret 2020

Wawancara. Mahrus Hasan. Desa Tayadun, 25 Maret 2020.

Wawancara. Mardi. Desa Bukamog, 12 Maret 2020.

Wawancara. Musa D Abdullah. Desa Bokat, 30 Maret 2020.

Wawancara. Ramli. Biau, 29 Maret 2020 
Wawancara. Salim. Desa Tang, 15

Maret 2020.

Wawancara. Samsudin Datu. Desa

Bongo, 18 Maret 2020.

Wawancara. Suleman Haruna. Desa

Bukamog, 26 Maret 2020.

Wawancara. Thalib. Desa Tayadun, 26

Maret 2020. 
Handep Jurnal Sejarah dan Budaya 